\title{
Effects of Pantothenic Acid Supplementation on Growth Performance, Carcass Traits, Plasma Parameters of Starter White Pekin Ducks Fed a Corn-Soybean Meal Diet
}

\author{
Jing Tang ${ }^{1,+} \oplus$, Yongbao $\mathrm{Wu}^{1,+}{ }^{+}$, Bo Zhang ${ }^{1}$, Zhiguo $\mathrm{Qi}^{2}{ }^{2}$, Dawei Luo ${ }^{1}$, Jian Hu ${ }^{1,3}$, Wei Huang ${ }^{1}$, Zhengkui Zhou ${ }^{1}$, \\ Ming Xie ${ }^{1}$ and Shuisheng Hou ${ }^{1, *}$ \\ 1 State Key Laboratory of Animal Nutrition, Key Laboratory of Animal (Poultry) Genetics Breeding and \\ Reproduction, Ministry of Agriculture and Rural Affairs, Institute of Animal Sciences, Chinese Academy of \\ Agricultural Sciences, Beijing 100193, China; tangjing198601@163.com (J.T.); woblin@163.com (Y.W.); \\ zhangb950414@163.com (B.Z.); LDW17862513746@163.com (D.L.); tothewings@163.com (J.H.); \\ hw-1115@163.com (W.H.); zhouzhengkui@caas.cn (Z.Z.); xieming01@caas.cn (M.X.) \\ 2 Beijing General Station of Animal Husbandry, Beijing 100101, China; qzguo886@163.com \\ 3 Newhope Liuhe Group Co., Ltd., Qingdao 266000, China \\ * Correspondence: houss@263.net \\ + These authors contributed equally to this work.
}

check for updates

Citation: Tang, J.; Wu, Y.; Zhang, B.; Qi, Z.; Luo, D.; Hu, J.; Huang, W.;

Zhou, Z.; Xie, M.; Hou, S. Effects of Pantothenic Acid Supplementation on Growth Performance, Carcass Traits, Plasma Parameters of Starter White Pekin Ducks Fed a Corn-Soybean Meal Diet. Animals 2021, 11, 2872. https://doi.org/ 10.3390/ani11102872

Academic Editors: Clive J. C. Phillips, Martina Pérez Serrano and Velmurugu Ravindran

Received: 4 August 2021

Accepted: 28 September 2021

Published: 30 September 2021

Publisher's Note: MDPI stays neutral with regard to jurisdictional claims in published maps and institutional affiliations.

Copyright: (C) 2021 by the authors. Licensee MDPI, Basel, Switzerland. This article is an open access article distributed under the terms and conditions of the Creative Commons Attribution (CC BY) license (https:// creativecommons.org/licenses/by/ $4.0 /)$.
Simple Summary: The yield of meat duck has increased over the past decade. Precise nutrition of ducks would contribute to improve growth performance and feed efficiency. As one of the important B-vitamins, pantothenic acid is essential for animals, and the deficiency of this vitamin could lead to growth depression, high mortality, and abnormal glucose metabolism. Similarly, pantothenic acid is also needed for ducks. The objectives of this study were to evaluate the effects of dietary pantothenic acid levels on growth performance, carcass traits, and plasma biochemical parameters of ducks, as well as the pantothenic acid requirement of ducks based on conventional corn-soybean meal diets. The results showed that among all ducks, the birds fed the basal diet without pantothenic acid supplementation had the lowest growth performance, breast meat yield, and plasma pantothenic acid and glucose contents. In addition, all these parameters increased linearly or quadratically as the dietary pantothenic acid level increased. The pantothenic acid requirements of starter male white Pekin ducks were $13.29-15.0 \mathrm{mg} / \mathrm{kg}$. The data potentially provides theoretical support for the utilization of pantothenic acid in duck production.

Abstract: This study aimed to evaluate the effects of different dietary pantothenic acid levels on growth performance, carcass traits, and plasma biochemical parameters of starter Pekin ducks from 1 to 21 days of age, as well as the pantothenic acid requirement of starter ducks. A total of 384 one-day-old male white Pekin ducklings were assigned randomly into 6 dietary treatments, each with 8 replicate pens of 8 ducks. Ducks were fed conventional basal corn-soybean diets containing $8.5,10.5,12.5,14.5,16.5$, and $18.5 \mathrm{mg} / \mathrm{kg}$ pantothenic acid for 21 days. Growth depression, poor pantothenic acid status, fasting hypoglycemia, and elevated plasma uric acid (UA) content were observed in the ducks fed the pantothenic acid-deficient basal diet $(p<0.05)$, and these adverse effects were ameliorated by pantothenic acid supplementation. Among all ducks, the birds fed the basal diet with no supplementation of pantothenic acid had the lowest body weight, average daily weight gain (ADG), average daily feed intake (ADFI), breast meat yield, and plasma pantothenic acid and glucose contents $(p<0.05)$, and the greatest plasma UA content $(p<0.05)$. In addition, all these parameters showed a linear or quadratic response as dietary pantothenic acid levels increased $(p<0.05)$. According to broken-line regression, the pantothenic acid requirements of starter male white Pekin ducks for body weight, ADG, and plasma pantothenic acid content were 13.36, 13.29, and $15.0 \mathrm{mg} / \mathrm{kg}$, respectively. The data potentially provides theoretical support for the utilization of pantothenic acid in duck production. 
Keywords: duck; pantothenic acid; requirement; growth performance; plasma parameter

\section{Introduction}

Pantothenic acid is a component of two coenzymes, coenzyme A and acyl-carrierprotein, which are involved in the metabolism of carbohydrates, lipids, and proteins [1,2]. Pantothenic acid deficiency could cause growth retardation, poor feathering, dermatosis, and high mortality in chicks, turkeys, and geese, and the requirements of this vitamin have been evaluated widely for these species [3-9]. Pantothenic acid is also essential for ducks and the deficiency of this vitamin could induce growth depression, exudate on eyelids, and high mortality in ducks [10-12]. The NRC [13] recommendation of pantothenic acid for white Pekin ducks is $11.0 \mathrm{mg} / \mathrm{kg}$ in either the starter or growing period, which refer to early literature [10]. Recently, we estimated pantothenic acid requirements of the modern strain of starter Pekin ducks based on the corn-soy isolate protein meal diets, ranging from 8.59 to $10.22 \mathrm{mg} / \mathrm{kg}$ [11]. However, in our previous study, these diets were not the typical diets for ducks. In commercial production of Pekin ducks, corn and soybean meal are still the most predominant ingredients in duck diets. In addition, pantothenic acid concentration in soybean meal $(16.0 \mathrm{mg} / \mathrm{kg})$ is much higher than that of soy protein isolate $(4.2 \mathrm{mg} / \mathrm{kg})$ [13]. In spite of this, corn-soybean meal diets are deficient in pantothenic acid for chicks [14]. Furthermore, the bioavailability of pantothenic acid varies in different feedstuff. It has been shown that pantothenic acid in corn and soybean meal is $100 \%$ bioavailable to chicks, whereas that in barley, wheat, and sorghum has about a $60 \%$ bioavailability [14]. Therefore, it is necessary to conduct a follow-up study to evaluate the pantothenic acid requirement of ducks on corn-soybean meal diets.

In addition, pantothenic acid deficiency induces abnormal glucose metabolism. It has been shown that pantothenic acid deficiency caused low fasting blood glucose levels and increased sensitivity to insulin in rats and dogs [15-19]. It is proposed that pantothenic acid appears to be part of a glucose carrier system [20]. Similarly, fasting hypoglycemia and decreased plasma insulin content were also observed in pantothenic-acid-deficient ducks based on corn-soy isolate protein meal basal diets [21]. However, whether pantothenic acid affects glucose metabolism in ducks is unknown based on corn-soybean meal diets. Therefore, the first objective of this study was to confirm the pantothenic acid requirement of ducks estimated in our previous study. Another objective of this study was to evaluate the effects of dietary pantothenic acid levels on the glucose metabolism of ducks.

\section{Materials and Methods}

All experimental procedures of the present study were performed strictly in accordance with the guidelines and were approved by the Animal Ethics Committee of Institute of Animal Sciences, Chinese Academy of Agricultural Sciences (Approval number: IASCAAS2019-19).

\subsection{Experimental Design, Animals, and Housing}

This study was conducted to evaluate the effects of different dietary pantothenic acid levels on growth performance, carcass traits, and plasma biochemical parameters of starter Pekin ducks from 1 to 21 days of age, as well as the pantothenic acid requirement of starter ducks. A total of 384 one-day-old male white Pekin ducklings (from Pekin duck breeding center in the Chinese Academy of Agricultural Sciences) were assigned randomly into 6 dietary treatments, each with 8 replicate pens of 8 ducks. Each replicate pen had a similar bird body weight. The birds were housed in plastic-wire-floored pens (length $2 \mathrm{~m} \times$ width $0.75 \mathrm{~m} \times$ height $0.4 \mathrm{~m}$ ) and had free access to pelleted feed and water. The initial temperature of $30^{\circ} \mathrm{C}$ was kept for 3 days and then gradually reduced to $22^{\circ} \mathrm{C}$ thereafter until 21 days of age. The lighting was kept continuous $(24 \mathrm{~h})$ throughout the whole study. 


\subsection{Diets}

The experimental diets were formulated to meet or exceed the recommendations for starter ducks provided by Ministry of Agriculture of China (2012) [22] for all nutrients except for pantothenic acid. A pantothenic acid-deficient basal diet was formulated with corn and soybean (Table 1). The corn-soybean basal diet was prepared as mash and then supplemented with $0,2,4,6,8$, or $10 \mathrm{mg}$ pantothenic acid $/ \mathrm{kg}$ diet as calcium pantothenate (99\% purity, Hangzhou Xinfu Technology Co. Ltd., Zhejiang, China) to produce 6 experimental diets. All diets were cold-pelleted at the room temperature. The pantothenic acid content of the basal diet was $8.5 \mathrm{mg} / \mathrm{kg}$, analyzed by high-performance liquid chromatography (HPLC; Agilent 1290, Agilent Technologies) coupled with triple-quadrupole mass spectrometry (LC/MS; Agilent 6470, Agilent Technologies). The calculated total pantothenic acid contents of the 6 experimental diets were 8.5, 10.5, 12.5, 14.5, 16.5, and $18.5 \mathrm{mg} / \mathrm{kg}$, respectively.

Table 1. Composition of the pantothenic acid-deficient basal diet from hatch to 21 days of age $(\mathrm{g} / \mathrm{kg}$ as-fed).

\begin{tabular}{|c|c|}
\hline Item & Value \\
\hline \multicolumn{2}{|l|}{ Ingredient, $\mathrm{g} / \mathrm{kg}$} \\
\hline Corn & 636 \\
\hline Soybean & 324 \\
\hline Limestone & 8 \\
\hline Dicalcium phosphate & 16 \\
\hline Vitamin and trace mineral premix ${ }^{a}$ & 10 \\
\hline Sodium chloride & 3 \\
\hline DL-Methionine & 2 \\
\hline L-Lysine·HCl & 1 \\
\hline Total & 1000 \\
\hline \multicolumn{2}{|l|}{ Calculated composition, g/kg } \\
\hline Metabolizable energy ${ }^{\mathrm{b}}, \mathrm{kcal} / \mathrm{kg}$ & 2900 \\
\hline Crude protein & 200.3 \\
\hline Calcium & 9.6 \\
\hline Nonphytate phosphorus & 4.2 \\
\hline Lysine & 11.1 \\
\hline Methionine & 5.1 \\
\hline Methionine + cysteine & 8.5 \\
\hline Threonine & 8.1 \\
\hline Tryptophan & 2.5 \\
\hline Arginine & 12.8 \\
\hline Pantothenic acid $^{\mathrm{c}}, \mathrm{mg} / \mathrm{kg}$ & 8.5 \\
\hline 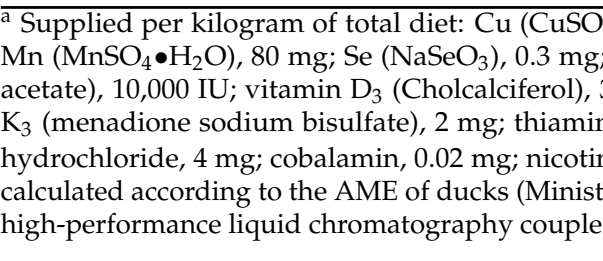 & $\begin{array}{l}\left.\mathrm{H}_{2} \mathrm{O}\right), 60 \mathrm{mg} ; \mathrm{Zn}(\mathrm{ZnO}), 60 \mathrm{mg} \text {; } \\
\text { de, } 1000 \mathrm{mg} \text {; vitamin A (retinyl } \\
\text { opheryl acetate), } 20 \mathrm{IU} \text {; vitamin } \\
; \text {; riboflavin, } 10 \mathrm{mg} \text {; pyridoxine } \\
\text { g; biotin, } 0.2 \mathrm{mg} \text {. }{ }^{\circ} \text { The value is } \\
\text { 2). }{ }^{\text {c }} \text { The value was analyzed by } \\
\text { spectrometry. }\end{array}$ \\
\hline
\end{tabular}

\subsection{Sample Preparation and Data Collection}

At 14 and 21 days of age, all the ducks were fasted overnight, then the body weight and diet consumption of the ducks from each pen were measured. The average daily weight gain (ADG), average daily feed intake (ADFI), and feed conversion ratio (FCR) were calculated for birds at different stages ( 1 to 14 days, and 1 to 21 days). At 21 days of age, after fasting overnight, two ducks close to the pen, of average body weight, were selected from each replicate pen and bled through a wing vein. Blood was collected into heparin sodium-containing tubes and plasma was separated, then stored at $-20^{\circ} \mathrm{C}$. These birds were then slaughtered, and the breast meat, leg meat, and abdominal fat were separated 
and weighed. The percentage yield for the breast meat, leg meat, and abdominal fat were expressed as relative weight to live body weight.

\subsection{Measurements}

The plasma activities of plasma alanine transaminase (ALT) and aspartate transaminase (AST), and plasma concentrations of total protein (TP), albumin (ALB), glucose, and uric acid (UA) were measured based on a spectrophotometric method using an automatic analyzer (Hitachi 7080, Tokyo, Japan) with corresponding kits (Maccura, Chengdu, China) based on their specifications.

Feed and plasma pantothenic acid concentrations were measured by HPLC (Agilent 1290) coupled with triple-quadrupole mass spectrometry (Agilent 6470) according to the methods described previously [23]. Prior to LC/MS analysis, feed and plasma samples were prepared according to the methods described previously [24,25]. The peak was identified by the pure authentic standards (Sigma-Aldrich, St. Louis, MO, USA).

\subsection{Statistical Analyses}

The data was analyzed by ANOVA using the general linear model (GLM) procedure of SAS software (SAS Inst. Inc., Cary, NC, USA) with the pen being the experimental unit. A significant difference among all dietary treatments was determined at $p<0.05$ by Turkey test. Variability in the data is expressed as the standard error of the means (SEM). The dose-response effect of supplemental pantothenic acid was computed using the polynomial comparison for linear and quadratic effects. The pantothenic acid requirements for ducks were estimated for the broken-line model by using the nonlinear regression analysis (NLIN) of SAS as described previously [26].

\section{Results}

\subsection{Growth Performance and Carcass Traits}

As is shown in Tables 2 and 3, the ducks fed the basal diet without pantothenic acid supplementation had the lowest body weight, ADG, and ADFI from hatch to 14 days of age $(p<0.05$, Table 2$)$ or from hatch to 21 days of age $(p<0.05$, Table 3$)$ among all ducks. As the dietary pantothenic acid increased, all these parameters increased linearly $(p<0.05$, Table 2; $p<0.05$, Table 3 ) and reached a plateau when the dietary pantothenic acid was above $12.5 \mathrm{mg} / \mathrm{kg}$. The dietary pantothenic acid levels did not affect FCR of ducks during the experimental period ( $p>0.05$, Table $2 ; p>0.05$, Table 3$)$.

Table 2. Effect of dietary pantothenic acid levels on growth performance of male white Pekin ducks from hatch to 14 days of age ${ }^{1}$.

\begin{tabular}{|c|c|c|c|c|}
\hline $\begin{array}{l}\text { Dietary Pantothenic Acid } \\
\text { (mg/kg) }\end{array}$ & $\begin{array}{l}\text { Body Weight } \\
\text { (g) }\end{array}$ & $\begin{array}{c}\text { ADG } \\
\text { (g/d/Bird) }\end{array}$ & $\begin{array}{c}\text { ADFI } \\
\text { (g/d/Bird) }\end{array}$ & $\begin{array}{l}\text { FCR } \\
(g / g)\end{array}$ \\
\hline 8.5 & $579^{c}$ & $37.5^{c}$ & $55.2^{b}$ & 1.47 \\
\hline 10.5 & $588^{b c}$ & $38.1^{b c}$ & $55.6^{\mathrm{b}}$ & 1.46 \\
\hline 12.5 & $602^{a b}$ & $39.1^{a b}$ & $57.3^{\mathrm{ab}}$ & 1.47 \\
\hline 14.5 & $601^{a b}$ & $39.0^{\mathrm{ab}}$ & $57.0^{\mathrm{ab}}$ & 1.46 \\
\hline 16.5 & $611^{\mathrm{a}}$ & $39.7^{\mathrm{a}}$ & $59.2^{\mathrm{a}}$ & 1.49 \\
\hline 18.5 & $602^{a b}$ & $39.1^{a b}$ & $58.3^{a}$ & 1.49 \\
\hline SEM & 2.94 & 0.21 & 0.36 & 0.01 \\
\hline \multicolumn{5}{|l|}{$p$-value } \\
\hline Pantothenic acid & 0.016 & 0.017 & 0.004 & 0.285 \\
\hline Pantothenic acid linear & 0.002 & 0.002 & $<0.001$ & 0.096 \\
\hline Pantothenic acid quadratic & 0.089 & 0.084 & 0.522 & 0.153 \\
\hline
\end{tabular}

ADG: average daily weight gain; ADFI: average daily feed intake; FCR: feed conversion ratio; SEM: standard error of the mean. ${ }^{1}$ Results are the means with $n=8$ per treatment. ${ }^{\text {a-c }}$ Means with different superscripts within the same column differ significantly $(p<0.05)$. 
Table 3. Effect of dietary pantothenic acid levels on growth performance of male white Pekin ducks from hatch to 21 days of age ${ }^{1}$.

\begin{tabular}{|c|c|c|c|c|}
\hline $\begin{array}{l}\text { Dietary Pantothenic Acid } \\
\text { (mg/kg) }\end{array}$ & $\begin{array}{l}\text { Body Weight } \\
\text { (g) }\end{array}$ & $\begin{array}{c}\text { ADG } \\
\text { (g/d/Bird) }\end{array}$ & $\begin{array}{c}\text { ADFI } \\
\text { (g/d/Bird) }\end{array}$ & $\begin{array}{l}\text { FCR } \\
(g / g)\end{array}$ \\
\hline 8.5 & $1155^{b}$ & $52.4^{\mathrm{b}}$ & $91.9^{\mathrm{b}}$ & 1.75 \\
\hline 10.5 & $1158^{\mathrm{b}}$ & $52.5^{b}$ & $91.9^{b}$ & 1.75 \\
\hline 12.5 & $1180^{a b}$ & $53.6^{\mathrm{ab}}$ & $94.0^{\mathrm{ab}}$ & 1.75 \\
\hline 14.5 & $1173^{a b}$ & $53.3^{\mathrm{ab}}$ & $93.4^{\mathrm{b}}$ & 1.76 \\
\hline 16.5 & $1194^{\mathrm{a}}$ & $54.3^{\mathrm{a}}$ & $97.1^{\mathrm{a}}$ & 1.79 \\
\hline 18.5 & $1190^{\mathrm{a}}$ & $54.1^{\mathrm{a}}$ & $97.0^{\mathrm{a}}$ & 1.79 \\
\hline SEM & 4.39 & 0.21 & 0.55 & 0.01 \\
\hline \multicolumn{5}{|l|}{$p$-value } \\
\hline Pantothenic acid & 0.027 & 0.028 & 0.004 & 0.073 \\
\hline Pantothenic acid linear & 0.006 & 0.006 & $<0.001$ & 0.015 \\
\hline Pantothenic acid quadratic & 0.526 & 0.511 & 0.849 & 0.309 \\
\hline
\end{tabular}

ADG: average daily weight gain; ADFI: average daily feed intake; FCR: feed conversion ratio; and SEM: standard error of the mean. ${ }^{1}$ Results are means with $n=8$ per treatment. ${ }^{\mathrm{a}, \mathrm{b}}$ Means with different superscripts within the same column differ significantly $(p<0.05)$.

As is shown in Table 4, dietary pantothenic acid levels affected breast meat yield $(p<0.05)$, but not the yield of leg meat and abdominal fat $(p>0.05)$. The ducks fed the basal diet with no supplementation of pantothenic acid had the lowest percentage of breast meat yield among all birds $(p<0.05)$, and it increased quadratically as dietary pantothenic acid increased $(p<0.05)$.

Table 4. Effect of dietary pantothenic acid levels on carcass traits of the 21-day-old male white Pekin ducks ${ }^{1,2}$.

\begin{tabular}{cccc}
\hline $\begin{array}{c}\text { Dietary Pantothenic Acid } \\
(\mathbf{m g} / \mathbf{k g})\end{array}$ & Breast Meat & Leg Meat & Abdominal Fat \\
\hline 8.5 & $1.91^{\mathrm{b}}$ & 9.86 & 0.74 \\
10.5 & $2.18^{\mathrm{a}}$ & 9.76 & 0.80 \\
12.5 & $2.17^{\mathrm{a}}$ & 10.0 & 0.85 \\
14.5 & $2.09^{\mathrm{a}}$ & 9.81 & 0.87 \\
16.5 & $2.16^{\mathrm{a}}$ & 9.96 & 0.85 \\
18.5 & $2.02^{\mathrm{ab}}$ & 9.88 & 0.78 \\
SEM & 0.026 & 0.75 & 0.16 \\
-value $_{\text {Pantothenic acid }}$ & 0.019 & 0.937 & 0.147 \\
Pantothenic acid linear & 0.446 & 0.746 & 0.213 \\
Pantothenic acid quadratic & 0.004 & 0.848 & 0.016 \\
\hline
\end{tabular}

SEM: standard error of the mean. ${ }^{1}$ Results are the means of 8 replicates of 2 ducks each. ${ }^{2}$ The percentage yield is calculated using the following equation: Yield $=$ (breast meat, leg meat, or abdominal fat weight $) \times 100 \% /$ live body weight. ${ }^{\mathrm{a}, \mathrm{b}}$ Means with different superscripts within the same column differ significantly $(p<0.05)$.

\subsection{Plasma Parameters}

The effects of dietary pantothenic acid levels on plasma biochemical parameters of starter white Pekin ducks are shown in Table 5. Dietary pantothenic acid levels did not affect plasma ALT, AST, TP, and ALB $(p>0.05)$. The ducks fed the basal diet without pantothenic acid supplementation had the lowest plasma pantothenic acid and glucose contents, but the greatest plasma UA content among all birds $(p<0.05)$. Plasma pantothenic acid and glucose contents increased while plasma UA content decreased as dietary pantothenic acid increased $(p<0.05)$. 
Table 5. Effect of dietary pantothenic acid levels on plasma biochemical parameters of the 21-day-old male white Pekin ducks ${ }^{1}$.

\begin{tabular}{|c|c|c|c|c|c|c|c|}
\hline $\begin{array}{l}\text { Dietary Pantothenic Acid } \\
\text { (mg/kg) }\end{array}$ & $\begin{array}{l}\text { ALT } \\
\text { (U/L) }\end{array}$ & $\begin{array}{l}\text { AST } \\
\text { (U/L) }\end{array}$ & $\begin{array}{c}\mathrm{TP} \\
(\mathrm{g} / \mathrm{L})\end{array}$ & $\begin{array}{l}\text { ALB } \\
(g / L)\end{array}$ & $\begin{array}{l}\text { Glucose } \\
(\mathrm{mmol} / \mathrm{L})\end{array}$ & $\begin{array}{c}\text { UA } \\
(\mu \mathrm{mol} / \mathrm{L})\end{array}$ & $\begin{array}{c}\text { Pantothenic Acid } \\
\text { (nmol/L) }\end{array}$ \\
\hline 8.5 & 34.1 & 14.8 & 17.1 & 0.98 & $8.94^{\mathrm{c}}$ & $117^{\mathrm{a}}$ & $500^{b}$ \\
\hline 10.5 & 34.7 & 16.4 & 16.4 & 1.02 & $9.30^{b}$ & $92.5^{b}$ & $509^{b}$ \\
\hline 12.5 & 34.1 & 14.3 & 16.6 & 0.98 & $9.48^{a b}$ & $92.2^{b}$ & $715^{a b}$ \\
\hline 14.5 & 37.3 & 14.7 & 17.2 & 1.01 & $9.81^{\mathrm{a}}$ & $93.4^{\mathrm{b}}$ & $768^{a}$ \\
\hline 16.5 & 41.3 & 15.0 & 16.9 & 0.99 & $9.51^{\mathrm{ab}}$ & $98.3^{b}$ & $723^{a b}$ \\
\hline 18.5 & 38.8 & 17.0 & 17.3 & 1.01 & $9.25^{b c}$ & $102^{a b}$ & $870^{a}$ \\
\hline $\begin{array}{c}\text { SEM } \\
p \text {-value }\end{array}$ & 1.49 & 0.54 & 0.14 & 0.07 & 0.06 & 2.61 & 38.7 \\
\hline Pantothenic acid & 0.675 & 0.637 & 0.332 & 0.397 & $<0.001$ & 0.046 & 0.011 \\
\hline Pantothenic acid linear & 0.129 & 0.506 & 0.225 & 0.533 & 0.020 & 0.423 & $<0.001$ \\
\hline Pantothenic acid quadratic & 0.932 & 0.339 & 0.230 & 0.650 & $<0.001$ & 0.007 & 0.653 \\
\hline
\end{tabular}

ALT: alanine transaminase; AST: aspartate transaminase; TP: total protein; ALB: albumin; UA: uric acid; SEM: standard error of the mean. ${ }^{1}$ Results are the means of 8 replicates of 2 ducks each. ${ }^{a-c}$ Means with different superscripts within the same column differ significantly $(p<0.05)$.

\subsection{Pantothenic Acid Requirement of Ducks}

The pantothenic acid requirements of starter ducks according to the broken-line regression are shown in Table 6 . Based on this regression, the pantothenic acid requirements of starter white Pekin ducks for body weight, ADG, and plasma pantothenic acid content were $13.36,13.29$, and $15.0 \mathrm{mg} / \mathrm{kg}$, respectively.

Table 6. Pantothenic acid requirements of male white Pekin ducks from hatch to 21 days of age based on broken-line regression analysis.

\begin{tabular}{|c|c|c|c|c|c|}
\hline Response Criterion & Regression & $\begin{array}{l}\text { Requirement } \\
\text { (mg/kg) }\end{array}$ & $\begin{array}{l}95 \% \text { Confidence } \\
\text { Interval }(\mathrm{mg} / \mathrm{kg})\end{array}$ & $p$-Value & $\mathbf{R}^{2}$ \\
\hline Body weight & $y=1182-6.33 \times(13.36-x)$ & 13.36 & 9.21 to 17.50 & 0.025 & 0.848 \\
\hline ADG & $y=53.69-0.31 \times(13.29-x)$ & 13.29 & 9.25 to 17.33 & 0.025 & 0.850 \\
\hline Plasma pantothenic acid & $y=796.3-50.11 \times(15.0-x)$ & 15.0 & 11.28 to 18.73 & 0.002 & 0.840 \\
\hline
\end{tabular}

ADG: average daily gain.

\section{Discussion}

\subsection{Growth Performance and Carcass Traits}

In contrast to a purified diet or the corn and soy protein isolate basal diet used in previous studies $[10,11]$, a corn and soybean basal diet was employed in the present study. The characteristic symptoms of pantothenic acid-deficient ducks reported by previous studies [10,11], such as poor feathering, dermatosis, excessive exudate from the eyes, and high mortality, were not observed in this study. The discrepancy between the present and previous results could be due to the difference in the basal diets; the pantothenic acid content of the basal diet in this study $(8.5 \mathrm{mg} / \mathrm{kg})$ was remarkably greater than that in previous study $(4.65 \mathrm{mg} / \mathrm{kg}$ ) [11], which may cause less severe pantothenic acid deficiency. In the present study, the ducks fed the corn-soybean meal basal diet without pantothenic acid supplementation had the worst growth performance and breast meat yield, but these negative effects can be alleviated by pantothenic acid supplementation, which is in line with the results in chicks, turkey poults, geese, and ducks [3-12]. Therefore, the results above suggest that a corn-soybean meal-based diet is deficient in pantothenic acid for ducks, and it is necessary to supplement pantothenic acid to diet. Furthermore, ducks fed a corn-soybean meal basal diet without pantothenic acid supplementation had a slightly lower growth performance than those birds with pantothenic acid supplementation in the present study, whereas the birds fed a corn-soy protein isolate basal diet had a dramatic decline in growth performance [11]. Our finding is consistent with the results in chicks, 
showing only a slight improvement in performance when $10 \mathrm{mg}$ pantothenic acid $/ \mathrm{kg}$ was added to a corn-soybean basal diet [14].

\subsection{Plasma Parameters}

Plasma or tissue pantothenic acid concentration could be a useful biomarker for pantothenic acid status. It has been shown that tissue pantothenic acid markedly decreased in pantothenic-acid-deficient shrimp, fish, and ducks [11,12,21,27-29]. In line with these previous studies, the ducks fed the basal diet without pantothenic acid supplementation had the lowest plasma pantothenic acid concentration among all ducks in the present study, which also showed the poorest growth and breast meat yield. However, these adverse effects could be eliminated by increasing dietary pantothenic acid levels. In agreement with studies in shrimp [29] and fish [27,28], the plasma pantothenic acid concentration increased linearly as the dietary pantothenic acid level increased in the present study, which was also accompanied with the simultaneous improvement of growth performance and carcass traits.

Pantothenic acid deficiency leads to abnormal glucose metabolism. In the present study, pantothenic acid deficiency caused fasting hypoglycemia and elevated UA content, confirming our previous results [21]. This finding is also consistent with previous studies in rats and dogs, showing pantothenic acid deficiency caused by low fasting blood glucose levels and increased sensitivity to insulin [15-19]. Recently, we found that pantothenic acid deficiency caused abnormal glucose absorption in ducks, indicated by a decreased expression of intestinal glucose transporter 2 (GLUT2), which may lead to hypoglycemia [21]. This explanation is supported by the previous finding that pantothenic acid appears to be part of a glucose carrier system [20]. In addition, pantothenic acid deficiency elevated the plasma UA content in ducks in the present study, indicating reduced excretion via the kidneys. Uric Acid is an oxidation end product of purine metabolism. This finding is consistent with previous studies in mammals showing that pantothenic acid deficiency imposes stress on the adrenal cortex, resulting in exhaustion of the gland and adrenal hypofunction $[17,18]$.

\subsection{Pantothenic Acid Requirement of Ducks}

The broken-line regression has been extensively employed to evaluate the pantothenic acid requirements for ducks [10-12], chicks [7], shrimp [29], and fish [27,28,30]. Furthermore, the body weight, ADG, or plasma pantothenic acid content of ducks showed a linear response to increasing dietary pantothenic acid levels. Therefore, this regression could be used to evaluate the pantothenic acid requirements of starter ducks in this study. Based on broken-line regression, the pantothenic acid requirements of starter male white In this study, Pekin ducks for body weight, ADG, and tissue pantothenic acid content were $13.36,13.29$, and $15.0 \mathrm{mg} / \mathrm{kg}$, respectively, and greater than 10.04, 10.05, and $10.22 \mathrm{mg} / \mathrm{kg}$ as reported by Tang et al. (2020a) [11] or $11 \mathrm{mg} / \mathrm{kg}$ as reported by Hegsted and Perry (1948) [10]. The differences between the present and previous results may be due to the different pantothenic acid contents in the basal diets $(8.5 \mathrm{mg} / \mathrm{kg}$ versus $4.65 \mathrm{mg} / \mathrm{kg})$. Furthermore, the pantothenic acid requirements estimated for tissue saturation $(15.0 \mathrm{mg} / \mathrm{kg})$ were greater than those for growth performance $(13.36$ and $13.29 \mathrm{mg} / \mathrm{kg})$ in the present study, which is in line with the findings in fish $[27,28]$ and ducks $[11,12]$. One explanation is that the tissue pantothenic acid concentration responds more rapidly to dietary pantothenic acid intake than growth performance [28].

\section{Conclusions}

The ducks fed the corn-soybean meal basal diet without pantothenic acid supplementation showed the depressed growth performance and breast meat yield of starter Pekin ducks, as well as fasting hypoglycemia, but these adverse effects can be reversed by pantothenic acid supplementation. According to broken-line regression, the pantothenic acid requirements for the modern breed of male white Pekin ducks from hatch to 21 days of 
age based on the corn-soybean basal diet for body weight, ADG, and plasma pantothenic acid content were $13.36,13.29$, and $15.0 \mathrm{mg} / \mathrm{kg}$, respectively. The data potentially provides theoretical support for the utilization of pantothenic acid in duck production.

Author Contributions: Data curation, J.T., Y.W., B.Z.; formal analysis, Z.Q., J.T., D.L., J.H.; writingoriginal draft preparation, J.T.; writing-review and editing, J.T., M.X., Z.Z., W.H., S.H.; supervision, S.H. All authors have read and agreed to the published version of the manuscript.

Funding: This research was sponsored by the Earmarked Fund for China Agricultural Research System (CARS-42), the Science and Technology Innovation Project of Chinese Academy of Agricultural Sciences (CXGC-IAS-09), and Taishan Industry Leadership Talent Project of Shandong province in China (TSCY20190108).

Institutional Review Board Statement: The study was conducted according to the guidelines of the Declaration of Helsinki, and approved by the Institutional Review Board (or Ethics Committee) of Institute of Animal Sciences of Chinese Academy of Agricultural Sciences (protocol code IASCAAS2019-19, 8 June 2019).

Informed Consent Statement: Not applicable.

Data Availability Statement: Not applicable.

Conflicts of Interest: The authors declare no conflict of interest.

\section{References}

1. Erdman, J.W.; Macdonald, I.A.; Zeisel, S.H. Present Knowledge in Nutrition, 10th ed.; John Wiley \& Sons: Hoboken, NJ, USA, 2012.

2. Smith, C.; Song, W. Comparative nutrition of pantothenic acid. J. Nutr. Biochem. 1996, 7, 312-321. [CrossRef]

3. Bauernfeind, J.; Norris, L.; Heuser, G. The Pantothenic Acid Requirement of Chicks. Poult. Sci. 1942, 21, 142-146. [CrossRef]

4. Jukes, T.H. The Pantothenic Acid Requirement of The Chick. J. Biol. Chem. 1939, 129, 225-231. [CrossRef]

5. Wang, B.; Zhang, X.; Yue, B.; Ge, W.; Zhang, M.; Ma, C.; Kong, M. Effects of pantothenic acid on growth performance, slaughter performance, lipid metabolism, and antioxidant function of Wulong geese aged one to four weeks. Anim. Nutr. 2016, 2, 312-317. [CrossRef]

6. Kratzer, F.H.; Williams, D. The Pantothenic Acid Requirement of Poults for Early Growth. Poult. Sci. 1948, 27, 518-523. [CrossRef]

7. Hegsted, D.M.; Riggs, T.R. The Pantothenic Acid Requirements of Chicks Receiving a Purified Diet. J. Nutr. 1949, 37, 361-367. [CrossRef]

8. Lepkovsky, S.; Bird, F.H.; Kratzer, F.H.; Asmundson, V.S. The Comparative Requirements of Chicks and Turkey Poults for Pantothenic Acid. Poult. Sci. 1945, 24, 335-339. [CrossRef]

9. Beer, A.E.; Scott, M.L.; Nesheim, M.C. The effects of graded levels of pantothenic acid on the breeding performance of white leghorn pullets. Br. Poult. Sci. 1963, 4, 243-253. [CrossRef]

10. Hegsted, D.M.; Perry, R.L. Nutritional studies with the duck V. Riboflavin and pantothenic acid requirements. J. Nutr. 1948, 35, 411-417. [CrossRef]

11. Tang, J.; Zhang, B.; Xue, M.; Shi, W.; Wu, Y.; Feng, Y.; Huang, W.; Zhou, Z.; Xie, M.; Hou, S. Pantothenic acid requirement of male White Pekin ducks from hatch to 21 days of age. Anim. Feed Sci. Technol. 2020, 269, 114637. [CrossRef]

12. Tang, J.; Zhang, B.; Liang, S.; Wu, Y.; Feng, Y.; Guo, Z.; Xing, G.; Jiao, J.; Zhou, Z.; Xie, M.; et al. Effects of pantothenic acid on growth performance and antioxidant status of growing male white Pekin ducks. Poult. Sci. 2020, 99, 4436-4441. [CrossRef]

13. NRC. Nutrient Requirements of Poultry, 9th ed.; The National Academies Press: Washington, DC, USA, 1994.

14. Southern, L.L.; Baker, D.H. Bioavailable Pantothenic Acid in Cereal Grains and Soybean Meal. J. Anim. Sci. 1981, 53, 403-408. [CrossRef]

15. Arnrich, L.; Hurley, L.S.; Forker, B.R.; Morgan, A.F. Response to Stress by Riboflavin-Deficient and Pantothenic Acid-Deficient Dogs. Am. J. Physiol. Content 1956, 184, 515-520. [CrossRef]

16. Arnrich, L.; Gram, M.R.; Morgan, A.F.; Nelson, M.R. Effect of Adrenal Hormones on Carbohydrate Metabolism in Riboflavin and Pantothenic Acid-Deficient Dogs. Am. J. Physiol. Content 1956, 186, 427-434. [CrossRef]

17. Hurley, L.S.; Morgan, A.F. Carbohydrate metabolism and adrenal cortical function in the pantothenic acid-deficient rat. J. Biol. Chem. 1952, 195, 583-590. [CrossRef]

18. Schultz, R.B.; Winters, R.W.; Krehl, W.A. The Adrenal Cortex of The Pantothenic Acid Deficient Rat: Modification of The Lesion by Acth and Cortisone Treatment. Endocrinology 1952, 51, 336-343. [CrossRef]

19. Winters, R.W.; Schultz, R.B.; Krehl, W.A. The Adrenal Cortex of The Pantothenic Acid-Deficient Rat: Carbohydrate Metabolism. Endocrinology 1952, 50, 388-398. [CrossRef]

20. Huan, P.H.; Van Hung, L. Use of the double Thiry-Vella loop in the study of the effects of pantothenic acid on intestinal absorption of glucose. Br. J. Nutr. 1972, 28, 405-408. [CrossRef] 
21. Tang, J.; Feng, Y.; Zhang, B.; Wu, Y.; Guo, Z.; Liang, S.; Zhou, Z.; Xie, M.; Hou, S. Severe pantothenic acid deficiency induces alterations in the intestinal mucosal proteome of starter Pekin ducks. BMC Genom. 2021, 22, 1-14. [CrossRef]

22. Ministry of Agriculture of China. Nutrient Requirements of Meat-Type Ducks of China; Standards Press of China: Beijing, China, 2012.

23. Lu, B.; Ren, Y.; Huang, B.; Liao, W.; Cai, Z.; Tie, X. Simultaneous Determination of Four Water-Soluble Vitamins in Fortified Infant Foods by Ultra-Performance Liquid Chromatography Coupled with Triple Quadrupole Mass Spectrometry. J. Chromatogr. Sci. 2008, 46, 225-232. [CrossRef]

24. Woollard, D.C.; Indyk, H.E.; Christiansen, S.K. The analysis of pantothenic acid in milk and infant formulas by HPLC. Food Chem. 2000, 69, 201-208. [CrossRef]

25. Petteys, B.J.; Frank, E.L. Rapid determination of vitamin B2 (riboflavin) in plasma by HPLC. Clin. Chim. Acta 2011, 412, 38-43. [CrossRef]

26. Robbins, K.R.; Saxton, A.; Southern, L.L. Estimation of nutrient requirements using broken-line regression analysis. J. Anim. Sci. 2006, 84, E155-E165. [CrossRef] [PubMed]

27. Qian, Y.; Li, X.-F.; Zhang, D.-D.; Cai, D.-S.; Tian, H.-Y.; Liu, W.-B. Effects of Dietary Pantothenic Acid on Growth, Intestinal Function, Anti-Oxidative Status and Fatty Acids Synthesis of Juvenile Blunt Snout Bream Megalobrama amblycephala. PLoS ONE 2015, 10, e0119518. [CrossRef] [PubMed]

28. Lin, Y.-H.; Lin, H.-Y.; Shiau, S.-Y. Estimation of dietary pantothenic acid requirement of grouper, Epinephelus malabaricus according to physiological and biochemical parameters. Aquaculture 2012, 324-325, 92-96. [CrossRef]

29. Shiau, S.-Y.; Hsu, C.-W. Dietary pantothenic acid requirement of juvenile grass shrimp, Penaeus monodon. J. Nutr. 1999, 129, 718-721. [CrossRef]

30. Wen, Z.-P.; Zhou, X.-Q.; Feng, L.; Jiang, J.; Liu, Y. Effect of dietary pantothenic acid supplement on growth, body composition and intestinal enzyme activities of juvenile Jian carp (Cyprinus carpiovar. Jian). Aquac. Nutr. 2009, 15, 470-476. [CrossRef] 